\title{
Ficções Caninas em Clarice Lispector e Machado de Assis
}

\author{
MARIA ESTHER MACIEL \\ Universidade Federal de Minas Gerais
}

\begin{abstract}
Este artigo aborda, sob um viés transdisciplinar, alguns personagens caninos da literatura brasileira, com ênfase em narrativas selecionadas de Machado de Assis e Clarice Lispector que apresentam cães como protagonistas e propõem reflexões instigantes sobre a convivência entre humanos e outras espécies animais. Para isso, busco discutir a noção de subjetividade animal e as estratégias ficcionais usadas por ambos os escritores na construção dos sujeitos caninos em suas obras.
\end{abstract}

Keywords: Personagens caninos; zooliteratura brasileira; subjetividade animal; Brasil; narrativa

Viver com o outro num mesmo lugar e ao mesmo tempo em que o outro vive é um ato de compartilhamento que não se restringe necessariamente à esfera dos humanos, haja vista as muitas as formas de convivência entre a nossa espécie e as dos outros seres. Não à toa, Roland Barthes, ao tratar do ato de viver junto, abordou algumas particularidades do convívio humano com animais, tomando como ponto de partida a figura de Robinson Crusoe após o naufrágio.

Isolado numa ilha desconhecida, Crusoe passa a experimentar uma solidão compartilhada com alguns viventes do lugar, entre eles, um cabrito e um papagaio, com os quais inicia uma relação de poder e de afeto ao mesmo tempo. Poder, pelas práticas de domesticação/escravização desses outros; afeto, por transformá-los em companheiros e, por vezes, em cúmplices. De acordo com Barthes, o náufrago cria o "afeto com poder" e usa "o poder para receber afeto," num processo "de impregnação, imprinting," que consiste em deixar no outro uma marca, uma impressão: "O jovem animal selvagem, no decorrer de 
uma experiência única, se apega ao homem: relação de subordinaçãodominação rapidamente fixada. Um filhote de lobo capturado ao nascer e criado pelo homem se comporta como um cão" (52). Na condição de um anacoreta involuntário (o isolamento, no caso, não é uma escolha, mas uma contingência), Robinson não apenas ameniza sua solidão ao se aproximar dos animais, como também reafirma sua condição de homem ao exercer um poder sobre eles. Assim, "revirados" e subtraídos de sua animalidade selvagem por meio dessa convivência forçada, os bichos sofrem um desvio de sua existência e são obrigados a assumir uma vida que não é propriamente a deles (Barthes 57). Eles recebem no corpo e no comportamento as marcas dessa domesticação, enquanto Crusoe, imprimindo também a esse exercício de dominação uma relação afetiva, empreende seu processo de hominização, pautado no jogo poder/afeto.

Sob essa perspectiva, os cães podem ser considerados criaturas exemplares do que Barthes chama de imprinting, visto que suas origens decorreram exatamente do processo de domesticação dos lobos que seguiam os homens ou rondavam seus acampamentos à procura de restos de caça. Tornaram-se, portanto, as criaturas que oferecem as conexões mais primárias entre a nossa espécie e as demais. E se a existência canina está intrinsecamente ligada a esse convívio, sendo impensável fora do contexto das culturas humanas, estas também foram afetadas por ele, num processo de impregnação recíproca entre as duas espécies. ${ }^{1}$ Como diz Susan McHugh: "the origins of dogs paradoxically coincide with their becoming part of everyday human life" (19).

Cães e humanos viraram, assim, antigos parceiros de vida, e dessa convivência milenar surgiu uma diversidade enorme de relações entre eles, que vão da exploração ao companheirismo, da hostilidade à solidariedade, da crueldade às trocas afetivas. E é nesse sentido que Donna Haraway, em seus instigantes estudos sobre essas relações, afirma que "dogs are about the inescapable, contradictory story of relationships in which none of the partners pre-exist the relating, and the relating is never done once and for all (12). Eles estão aqui para viverem com. E assim, segundo Haraway, "dogs and people figure a universe" (21).

\footnotetext{
1 Pode-se dizer que o estudo dessas convivências interespecíficas tem mobilizado o interesse graças, sobretudo, à emergência da questão do animal e das relações entre seres humanos e não humanos no âmbito acadêmico e à luz das demandas contextuais do presente.
} 


\section{Cães literários}

No âmbito da literatura ocidental, os limites/liames entre humanidade e animalidade advindos do convívio dos homens com os caninos têm sido abordados de forma plural por autores de distintas épocas e nacionalidades, sendo que o registro mais antigo e canônico é o que se refere ao cão Argos, da Odisseia de Homero, o qual ganha nas páginas finais da epopeia uma grande importância, por figurar como o único vivente a identificar Ulisses, quando este — disfarçado de mendigo — retorna a Ítaca após vinte anos de aventuras pelo mundo.

Numa comovente demonstração de lealdade, o velho cão não apenas reconhece e festeja a volta do dono, como morre em seguida, mostrando que havia sobrevivido por tanto tempo só para rever o amigo ausente. E é nesse momento que o herói chora pela primeira e única vez na história. Percebe-se que Argos, ao se valer de outras faculdades além do conhecimento racional, oferece ao antigo dono uma incontestável prova de amor, numa demonstração de fidelidade e resistência únicas, capazes de levar às lágrimas o grande herói.

Tendo em vista essa capacidade canina de tocar o ponto mais recôndito da sensibilidade humana e demonstrar atitudes de solidariedade, cumplicidade e afeto, além de uma admirável memória, é que Marjorie Garber, no seu livro Dog Love, constata que os cães acabaram por se tornar o repositório por excelência das qualidades que faltam aos humanos ou nestes se rarefazem, já que, segundo ela, "paradoxically, the quintessence of the 'human' is often found in the dog" (34). A isso a estudiosa ainda acrescenta o fato de que os cães podem trazer à tona o que de melhor existe em nós.

No entanto, não apenas de afetos e cumplicidade são construídos os laços entre homens e caninos na nossa sociedade, haja vista a hierarquia que marca as relações da espécie humana com as demais espécies. Se o amor e o companheirismo são comumente ressaltados na nossa relação com os cães, não se pode ignorar a situação à margem que eles também têm ocupado na sua convivência com os homens no decorrer dos séculos. Subjugados, maltratados, rejeitados, descartados, muitas vezes representam a escória social e, nessa condição, chegam a servir de metáforas para os seres humanos que também vivem à margem da vida social e política, ou como diria Giorgio Agamben, em Homo Sacer, vivem uma "vida nua" que é "indigna de ser vivida" (132). 
Pode-se dizer que, dessa miríade de contradições que compõe as relações entre humanos e caninos, a literatura ocidental vem se nutrindo ao longo dos séculos, desde a antiguidade clássica. Ora como protagonistas de histórias de amor ou de aventuras, ora como seres submetidos a situações de grande adversidade, ora dotados de saberes surpreendentes, os cães nunca deixaram de se fazer presentes em textos literários de várias procedências.

No que tange à literatura brasileira, os personagens caninos são frequentes e por vezes ocupam espaços de relevo nas narrativas, embora nem sempre assumam o papel de protagonistas. Aparecem também, com abundância, em poemas de autores do passado e do presente, inserindo-se, de maneira incisiva, em obras de poetas contemporâneos. ${ }^{2}$

Sem dúvida, o canino mais canônico das letras brasileiras é a cachorra Baleia de Vidas secas (1938), que protagoniza algumas das cenas mais pungentes desse romance de Graciliano Ramos. Consistente como personagem, Baleia exerce um papel central não apenas dentro do pequeno núcleo familiar de retirantes, como também na constituição da própria narrativa (Maciel 82-85).

Tida como uma integrante da família, ela é solidária, sensível e inteligente, que contribui para a sobrevivência de todos em meio às agruras da seca nordestina. Nesse sentido, ela ocupa a posição de sujeito dentro da novela, mas fora das armadilhas do antropomorfismo, visto que Ramos a constrói como um ser que, pela estreita convivência com os humanos, tem sua animalidade contaminada por essa proximidade, na mesma proporção em que a animalidade dos humanos se intensifica, graças à imersão deles num mundo em estado bruto, onde estão condenados à experiência da "vida nua." Daí poder-se afirmar que, em Vidas secas, as espécies se misturam de forma intrínseca, num processo de impregnação recíproca.

Além dessa obra, outra a apresentar um cachorro como figura medular, que se confunde com um personagem humano e assume com ele o protagonismo da narrativa, é Quincas Borba, de Machado Assis, um romance também canônico da moderna literatura brasileira, sobre o qual me deterei mais adiante. Já a partir do século XX, os personagens caninos de maior relevo na literatura brasileira aparecem em alguns romances/novelas, como Campo geral (1956) de

\footnotetext{
${ }^{2}$ Vale ressaltar uma significativa presença canina em livros de Hilda Hilst, Wilson Bueno, Nuno Ramos e Carlito Azevedo.
} 
Guimarães Rosa, Uma Vida em Segredo (1964), de Autran Dourado, Confissões de um Vira-Lata (1972), de Orígenes Lessa, e Até o dia em que o cão morreu (2003), de Daniel Galera. Narrativas variadas de Clarice Lispector, a exemplo de Quase de Verdade, "Tentação" e "O Crime do Professor de Matemática", entram nesse repertório, além de contos de João do Rio ("Os Cães”), Lygia Fagundes Telles ("Cachorro se Chama com Assobio”), Rachel de Queiroz ("Minha Amiga Flicka") e Carlos Drummond de Andrade ("Meu Companheiro"), entre outros. ${ }^{3}$

Todos esses escritos exploram diversas situações da convivência entre homens e cães, nas quais, muitas vezes, a empatia humana em relação aos caninos se converte num processo de identificação ou de troca de papeis, o que ocorre, sobretudo, nas narrativas de Machado de Assis e Clarice Lispector, nas quais as noções de animalidade/humanidade se imbricam por vias inquietantes, e a própria noção de subjetividade se torna interespecífica. Numa inversão da ordem cronológica entre os escritores, começo com Clarice.

\section{Subjetividades híbridas: Clarice Lispector e seu cão}

Ulisses foi o nome do terceiro e último cachorro que frequentou a vida de Clarice Lispector. ${ }^{4}$ Um nome que, a princípio, poderia remeter ao personagem homônimo de Homero e, por extensão reversa, ao cão Argos, mas que, segundo

\footnotetext{
${ }^{3}$ Dentre as antologias de contos caninos publicadas no Brasil, destacam-se: Rogério Ramos; e Costa. No século XIX, alguns autores brasileiros também incluíram cães como personagens de contos, como Machado de Assis ("Miss Dollar"); Artur Azevedo; e Raul Pompeia.

${ }^{4}$ Os outros dois cachorros foram Dilermando e Jack. Sobre o primeiro, que ela adotou em Nápoles, mas teve que deixar com outra família quando de lá se mudou, a escritora escreveu: "Desse Dilermando eu teria muito a contar. Nossas relações eram tão estreitas, sua sensibilidade estava de tal modo ligada à minha que ele pressentia e sentia minhas dificuldades. Quando eu estava escrevendo à máquina, ele ficava meio deitado ao meu lado, exatamente como a figura da esfinge, dormitando. Se eu parava de bater por ter encontrado um obstáculo e ficava muito desanimada, ele imediatamente abria os olhos, levantava alto a cabeça, olhava-me, com uma das orelhas de pé, esperando. Quando eu resolvia o problema e continuava a escrever, ele se acomodava de novo na sua sonolência povoada de que sonhos - porque cachorro sonha, eu vi. Nenhum ser humano me deu jamais a sensação de ser tão totalmente amada como fui amada sem restrições por esse cão" ("Bichos" 222). Consta que o conto "O crime do professor de matemática," do livro Laços de família, foi escrito a propósito de Dilermando.
} 
fontes biográficas da autora, foi uma homenagem ao seu psicoterapeuta Ulysses Girsoler, que a atendera na Suíça em meados dos anos $1940 .^{5}$

Transformado em personagem-narrador do livro infantil Quase de verdade (1978), o cachorro também aparece em Um sopro de vida (Pulsações), “um livro de não memórias" iniciado por ela em 1974 e concluído em 1977, às vésperas de sua morte, o que evidencia sua grande importância na vida de Clarice. ${ }^{6}$ Sabe-se que ele era um cão mestiço que, entre outras peculiaridades, fumava cigarros, tomava uísque e Coca-Cola, além de ser, segundo a própria escritora, "um pouco neurótico." Consta ainda que ela o deixava fazer o que bem entendesse no apartamento que dividiu com ele nos anos 1970, no Rio de Janeiro, respeitando a índole rebelde do cão e suas maneiras malcriadas. Teria também recebido da escritora outros nomes que não Ulisses, como "Vicissitude," "Pitulcha" e "Pornósio" (Moser 483).

Em Um sopro de vida, obra sem gênero literário definido, Ulisses transita entre a ficção e a realidade, ao ser convertido no cachorro da personagem Ângela Pralini, que, por sua vez, pode ser considerada uma espécie de "eu" fictício da própria autora, uma materialização em palavras de sua "trêmula identidade." Ao longo de todo o livro, encontram-se diálogos entre Ângela e alguém nomeado apenas de "Autor," que assume o papel de narrador (e personagem) da obra, o que deflagra um instigante jogo de identidades, já que Clarice se mistura com ambos, inserindo elementos de sua própria vida no espaço ficcional. Ângela seria, assim, o reflexo invertido do narrador/autor que, ao mesmo tempo, seria o reflexo invertido de Clarice. Daí que, ao falar de Ângela, tal narrador dúplice parece estar falando em nome da escritora no momento em que ela escreve: "Ângela é mais do que eu mesmo. Ângela não sabe que é personagem. Aliás eu também talvez seja o personagem de mim mesmo. Será que Ângela sente que é um personagem? Porque, quanto a mim, sinto de vez em quando que sou o personagem de alguém. É incômodo ser dois: eu para mim e eu para os outros" (29).

O cachorro Ulisses entra, assim, como o ponto de realidade que aproxima personagem, narrador e escritora, por ter o mesmo nome e as mesmas características do cão de verdade, embora convertido em uma figura de ficção.

\footnotetext{
${ }^{5}$ Vale lembrar que Ulisses é também o nome do personagem de Uma Aprendizagem ou O Livro dos Prazeres. Sobre a relação de Clarice com Ulysses Girsoler, ver Moser 257-60; 438-39.

${ }^{6} \mathrm{O}$ livro foi organizado posteriormente por Olga Borelli e publicado em 1978.
} 
Ou seja, o cão possibilita um desdobramento do jogo de identidades instaurado e, paradoxalmente, desvela esse mesmo jogo, tornando inequívoco o liame entre os três sujeitos ficcionais do livro. Além disso, ele entra na esfera íntima da personagem, misturando-se com ela, a ponto de o narrador dizer, sob a persona de Autor: "Ângela, nobre vira-lata, segue a trilha do seu dono, que sou eu" (56). Isso se repete na voz da personagem, quando ela admite: "Eu e o meu cachorro Ulisses somos vira-latas" (60). Uma afirmação que surge depois de ela já ter dito, algumas páginas antes, que em sua vida "tem um cachorro dentro latindo" (46). Dessa forma, realidade e ficção, identidade e alteridade, espaços exterior e interior, gêneros masculino e feminino se interseccionam, compondo um conjunto intrincado que desafia quem se aventura pelas páginas do livro.

No que tange especificamente à subjetividade, esse desafio ultrapassa inclusive os próprios limites do humano, ao abarcar também a esfera animal, pois há uma interseção entre as espécies humana e canina que nos remete, mais uma vez, à ideia barthesiana de impregnação e às intrínsecas relações entre homens e cães. Feitos de porosidade, os dois mundos, nessa e em outras obras de Clarice Lispector, contagiam-se reciprocamente, o que torna difícil precisar o ponto de confluência entre animalidade e humanidade nos personagens em relação.

Se Ângela, Ulisses, o narrador e a própria Clarice têm uma dimensão humana e canina ao mesmo tempo, isso só reforça o caráter híbrido da própria noção de sujeito que atravessa os escritos da escritora e condiz, no caso dos cães, com a experiência do viver junto. No caso dos cães, abrir mão dessa hibridez no trato da subjetividade a eles inerente é praticamente impossível, já que estão-e sempre estiveram - sob o signo da heteronomia, ou seja, sua condição de sujeitos está determinada pela interferência humana.

O filósofo e etólogo francês Dominique Lestel tem investigado essa questão dos sujeitos animais heterônomos, fora do âmbito da literatura. Ele sustenta - na contramão do pensamento ocidental legitimado pela filosofia de viés cartesiano-que os animais são de fato sujeitos, ainda que vários permaneçam na heteronomia, em decorrência da estreita proximidade que mantêm com os humanos. O que não impede, contudo, que estabeleçam com estes uma rede complexa de relações, através da qual adquirem uma dimensão subjetiva crucial, desenvolvendo comportamentos de grande densidade e uma 
posição ativa dentro de comunidades e grupos interespecíficos. ${ }^{7}$ Outros, por outro lado, podem se tornar pessoas com grande autonomia, sem a interferência de outrem, a exemplo dos chimpanzés da Tanzânia ou dos elefantes do Quênia, entre outros. ${ }^{8}$

No território literário, percebe-se um empenho de muitos escritores em capturar - pelo exercício da imaginação e dos sentidos — a dimensão subjetiva dos bichos, numa travessia das fronteiras que destes nos separam. Em O sopro de vida, Clarice Lispector aborda esse desafio, mas convicta da impossibilidade de realizar isso de forma efetiva. Diz o narrador: "Se eu pudesse descrever a vida interior de um cachorro eu teria atingido um cume. Ângela também quer entrar no ser-vivo de seu Ulisses" (60).

Essa impossibilidade advém, certamente, do abismo da não compreensão que decorre da ausência de uma linguagem comum entre humanos e não humanos, apesar da existência, entre cães e homens, de maneiras alternativas de comunicação, as quais são quase sempre exploradas pelos escritores em seus relatos ou em cenas centradas em sua relação de cumplicidade com os companheiros caninos.

Numa das passagens do mesmo livro, lê-se este dizer de Ângela, depois de ela afirmar que procura entender seu cão: "Eu sei falar uma língua que só o meu cachorro, o prezado Ulisses, meu caro senhor, entende. $\hat{E}$ assim: dacoleba, tutiban, ziticoba, letuban. Joju leba, leba jan? Tutiban leba, lebajan. Atotoquina, zefiram. Jetobabe? Jetoban. Isso quer dizer uma coisa que nem o imperador da China entenderia" (60). Trata-se de uma língua secreta, inventada como via de acesso ao ser canino de Ulisses, a qual atesta não apenas a cumplicidade entre os dois, como também o empenho da mulher em levar a cabo, por meio da imaginação, tal desafio de trespassar as fronteiras. Ainda assim, permanece o desejo do impossível: "Um dia desses vai acontecer: meu cachorro vai abrir a boca e falar" (60).

\footnotetext{
${ }^{7}$ Podem ser inseridos nesse registro animais domésticos e rurais.

8 Lestel acrescenta que essa categoria de sujeito animal forte, autônomo, ainda não foi suficientemente investigada, embora seu estudo já esteja avançado em alguns casos, como evidenciam as pesquisas de campo sobre chimpanzés, da primatologista Jane Goodhal. Poderíamos acrescentar aqui também o trabalho do etólogo americano Carl Safina, estudioso de elefantes, orcas e golfinhos.
} 
Cabe observar que a afirmativa de que o cachorro "só falta falar," tão recorrente nos discursos de quem convive com um, advém, obviamente, do reconhecimento da inteligência e da sensibilidade acentuadas dos cães, assim como do desejo de que eles compartilhem conosco um mesmo registro linguístico, a exemplo da frase de Ângela. Mas é uma afirmativa que, no campo das teorias amparadas na pretensa supremacia da espécie humana sobre as demais, vem frequentemente atrelada à certeza de que a linguagem humana é a única a merecer o nome de linguagem.

Jacques Derrida questiona isso de forma veemente, ao discutir o contraponto, estabelecido nos discursos predominantes sobre a noção de sujeito, entre "o reagir dos animais" e "o responder dos humanos." Para isso, Derrida evoca Michel de Montaigne, a quem chama de "um anticartesiano por antecipação," lembrando que, em pleno século XVI, esse filósofo já reconhecia no animal "mais que um direito à comunicação, ao signo, à linguagem como signo: um poder de responder" (19). Derrida cita também um excerto do ensaio, "Apologia de Raymond Sebond": "Como eles não falariam entre eles? Eles falam a nós e nós a eles. De quantas maneiras nós falamos a nossos cachorros? E eles nos respondem. Outra linguagem, outros chamamentos partilhamos com eles e com os pássaros, com os porcos, os bois, os cavalos, e mudamos de idioma de acordo com a espécie" (19).

O que Derrida ressalta em suas considerações (e o que Montaigne parecia ressaltar ao marcar determinadas habilidades comunicativas dos animais) não é, obviamente, a suposta capacidade de eles fazerem uso da linguagem verbal dos humanos, mas, sim, a existência de possíveis outras formas de linguagem, por meio das quais os bichos se comunicariam com seus pares e com viventes de outras espécies, incluindo a humana. Nesse sentido, a falta de linguagem humana entre os bichos não seria de fato uma falta, uma privação. ${ }^{9}$

\footnotetext{
${ }^{9}$ É curioso que até hoje grande parte da filosofia ocidental recuse-se a reconhecer as linguagens animais. Agamben, por exemplo descreve uma paisagem cheia de "inauditas vozes animais" (silvos, trilos, chilros, assobios, cochichos, cicios, etc.), e diz que, enquanto cada animal tem seu som, nascido imediatamente de si, nós (os humanos)—os únicos "sem voz no coro infinito das vozes animais"- "provamos do falar, do pensar" (156). Colocando em contraponto voz e fala, phoné e logos, Agamben lança uma frase quase-verso: "Em seu trilo, é claro: o grilo não pensa" (56). Ou seja, por vias oblíquas, Agamben não deixa de reforçar com tal imagem a ideia de que o animal é desprovido de linguagem.
} 
Lispector parece condizer com essa ideia em seus escritos, mostrando não apenas outras possibilidades de comunicação entre nós e eles, como também formas alternativas de trazer para a esfera da linguagem humana a linguagem animal. Isso se dá a ver, de maneira lúdica, em Quase de verdade, livro dirigido ao público infantil, no qual a história é contada a partir do ponto de vista de Ulisses, embora Clarice não the dê diretamente a fala humana, como é comum nas histórias infantis que têm bichos como narradores ou personagens. Como o cachorro informa no início da narrativa, ele "late" a história em primeira pessoa e ela "traduz" os latidos em palavras. Ou seja, a escritora cria um artifício para tornar possível a "fala" canina, sem se render inteiramente aos recursos do antropomorfismo, ainda que uma boa dose de humanização seja inevitável nesse caso. Afinal, trata-se de um cachorro em intrínseca proximidade com sua dona e, portanto, atravessado pelos eflúvios dessa convivência, além do quê, a linguagem soberana continua sendo a verbal, humana. Por haver a mediação de Clarice no processo de transposição dos "latidos" para o registro verbal, a linguagem canina acaba por não se sustentar fora dos limites humanos.

A narrativa começa com as seguintes palavras: "Sou um cachorro chamado Ulisses e minha dona é Clarice. Eu fico latindo para Clarice e ela-que entende o significado de meus latidos - escreve o que eu lhe conto." Duas camadas de subjetividade se interpõem: a do animal (que conta a história segundo sua própria lógica) e a do sujeito humano, que reproduz verbalmente o que o primeiro relata. Com esse recurso de sobreposição, Clarice retira, como já foi dito, o animal da esfera exclusivamente antropomórfica, sem tentar omitir o fato de a narrativa ser uma construção humana, feita de linguagem verbal. O que o cão expressa como narrador-personagem passa, assim, como uma tradução do que, supostamente, Ulisses teria para contar. Dessa forma, os leitores ficam sabendo de suas aventuras insólitas, narradas em primeira pessoa, mesmo que pela tradução da personagem/autora Clarice.

\section{Na outra margem do humano: Quincas Borba, de Machado de Assis}

Nem sempre, porém, a tradução do que se passa na cabeça de um cachorro é reconhecida como sendo possível de ser transmitida pela linguagem humana, o que se constata neste fragmento do primeiro grande romance canino da literatura brasileira, Quincas Borba, de Machado de Assis: "Mas a verdade é 
que este olho que se abre de quando em quando para fixar o espaço, tão expressivamente, parece traduzir alguma coisa, que brilha lá dentro, lá muito ao fundo de outra coisa que não sei como diga, para exprimir uma parte canina, que não é a cauda nem as orelhas. Pobre língua humana!" (662). Tais palavras referem-se ao cão homônimo do personagem humano que dá título ao livro e com quem o cachorro se mistura ao longo da história. Na passagem, o canino, já tendo perdido o dono - um filósofo dotado de uma esquisitice genial—está sob os cuidados de Rubião, herdeiro único da fortuna do falecido amigo, e encontra-se mergulhado em pensamentos, deitado num canto da casa. Entretanto, seu estado interno apresenta-se como um desafio para o próprio narrador, incapaz de traduzir para a língua humana o que se passa dentro do animal.

Essa incompreensão reafirma-se logo depois, quando o cachorro adormece, sonha e acorda, já esquecido de seus males, embora com uma certa melancolia que o próprio narrador não sabe muito bem como definir. Afinal, o que pode a razão humana diante de uma racionalidade outra, que não se circunscreve aos domínios da lógica legitimada pelos homens? Como decifrar as ideias de um cachorro apenas com os parcos recursos do pensamento humano?

Trata-se de uma cena em que, à diferença das que Lispector nos apresenta, é constatada a insuficiência da língua verbal para decifrar ou traduzir a alteridade radical de um ser de outra espécie. O que vem atestar um dos propósitos machadianos nesse livro: ironizar a pretensa soberania humana em relação aos animais não humanos, aqui representados pelos cães.

O próprio Humanitismo, sistema filosófico criado pelo personagem Quincas Borba para "arruinar todos os demais sistemas", reforça tal propósito. Já presente no romance Memórias Póstumas de Brás Cubas (1881), como uma paródia do humanismo logocêntrico do Ocidente e de diversos determinismos presentes no século XIX, reaparece em Quincas Borba intrinsecamente atrelado à figura do cachorro, numa provável remissão à filosofia cínica.

Vale lembrar que o Cinismo, desde suas origens na Grécia por volta do século IV AEC, tem um estreito vínculo com a figura do cão, uma vez que a palavra cínico deriva do termo kinos, (cão em grego) e condiz com o modelo de vida adotado por Diógenes de Sínope (403-329 AEC), o filósofo "vira-lata," que tomou a vida canina como modelo para a sua própria existência. Viver como um cão, fora dos limites impostos pelas convenções sociais, foi sua opção 
e sua maldição (perante os olhos da racionalidade humana), o que o tornou o principal expoente de tal corrente filosófica. Tanto que, após sua morte, foi construída a estátua de um cão em sua homenagem.

Acrescente-se a isso o fato de que o movimento cínico, criado por Antístenes, não foi apenas intelectual, mas comportamental. Como explica Hélio Soares do Amaral, "o movimento dos Cães-Filósofos passou pela história como sendo o filosofar na prática—o bios kunikós"—o que se evidenciava na escolha de vestimentas despojadas, alimentação estrita e moradia alternativa (43). A opção pela vida indigente estava vinculada também à vida em trânsito, feita de perambulações e noites passadas ao relento. Eles almejavam, segundo Amaral, a autossuficiência para se libertarem do escravizante sistema de desejos (43). Daí que Diógenes, o principal discípulo de Antístenes, que levou o cinismo a um ponto de maior radicalidade, tenha considerado a natureza como a única potência capaz de ultrapassar a esfera humana, pautando sua própria vida numa atitude anticultural baseada na pobreza e na vida nômade, em afinidade com os cães de rua que perambulam sem rumo certo à cata de comida. Sabe-se, ainda, que ele justificava o epíteto de cão, dizendo: "Faço festas aos que me dão alguma coisa, lato contra os que não me dão nada e mordo os perversos" (Reale e Antiseri 231-33).

Logo no início do romance de Machado de Assis, a caracterização de Quincas Borba, o homem, como um "náufrago da existência"-já sugere nítidas confluências entre ele a figura atópica/atípica de Diógenes: "Este Quincas Borba, se acaso me fizeste o favor de ler as Memórias Póstumas de Brás Cubas, é aquele mesmo náufrago da existência, que ali aparece, mendigo, herdeiro inopinado, e inventor de uma filosofia" (644). O fato de o personagem ter atribuído seu próprio nome ao cão só reforça essas confluências, visto que o nome compartilhado indica uma identificação do homem com o animal, e também provoca uma deliberada confusão entre os dois. Ademais, o Quincas Borba canino - apresentado pelo narrador como "um bonito cão, meio tamanho, pelo cor de chumbo, malhado de preto" (645)—ocupa um lugar privilegiado na vida do Quincas Borba humano, o que embaralha mais ainda as identidades de um e de outro: "Quincas Borba levava-o para toda parte, dormiam no mesmo quarto. De manhã, era o cão que acordava o senhor, trepando ao leito, onde trocavam as primeiras saudações. Uma das 
extravagâncias do dono foi dar-lhe o seu próprio nome; mas, explicava-o por dois motivos, um doutrinário, outro particular" (648).

Se, em Diógenes, as noções de humanidade, animalidade e loucura se misturaram de maneira indiscernível, o mesmo se pode dizer com relação a Quincas Borba, tão filósofo quanto louco, que se mistura à figura de seu cão. Num século em que o racionalismo cientificista se impunha como a principal das diretrizes do pensamento do tempo, legitimando um conceito de humano e de humanismo a partir de uma instrumentalização da animalidade, Machado de Assis mina os limites entre razão e loucura, homem e animal, numa evidente crítica ao humanismo cientificista $\mathrm{e}$ às dicotomias do pensamento antropocêntrico (Maciel).

Em Quincas Borba, o entrelaçamento entre homem e cão permanece mesmo após a morte do filósofo. Rubião, que deste herda a fortuna sob a condição de cuidar do cachorro, chega a ficar confuso (e assustado) com a possibilidade de o espírito do amigo ter se alojado no corpo do canino. Tal inquietação se manifesta em alguns momentos do romance, como este:

Olhou para o cão, enquanto esperava que lhe abrissem a porta. $\mathrm{O}$ cão olhava para ele, de tal jeito que parecia estar ali dentro o próprio e defunto Quincas Borba; era o mesmo olhar meditativo do filósofo, quando examinava negócios humanos... Novo arrepio; mas o medo, que era grande, não era tão grande que lhe atasse as mãos. Rubião estendeu-as sobre a cabeça do animal, coçando-lhe as orelhas e a nuca. (681)

Esse temor de que o espírito do homem Quincas Borba estivesse frequentando o corpo do cão Quincas Borba não deixa de levar os leitores - conduzidos pelo tom irônico do narrador - a uma desconfiança quanto à própria sanidade de Rubião, a qual acaba por se confirmar. É como se o personagem, em processo progressivo de enlouquecimento, tivesse herdado do amigo, além do cachorro e do dinheiro, o seu "grãozinho de sandice."10

\footnotetext{
${ }^{10}$ No capítulo IV de Quincas Borba, o narrador diz: "Saberia Rubião que o nosso Quincas Borba trazia aquele grãozinho de sandice, que um médico supôs achar-lhe? Seguramente, não; tinha-o por homem esquisito. É, todavia, certo que o grãozinho não se despegou do cérebro de Quincas Borba, — nem antes, nem depois da moléstia que lentamente o comeu" (644-45).
} 
Assim, loucura e animalidade potencializam os laços entre os três, Rubião e os dois Quincas Borba, mesmo que um deles se manifeste em estado de ausência, ou seja, faz-se presença em ausência através do cão. O "viver junto" é levado às últimas consequências, culminando numa quase indiscernibilidade entre os personagens. Mesmo porque o cão, no romance, ocupa um lugar de sujeito que pensa, sente, interpreta, não necessariamente por estar impregnado dos chamados "próprios do humano," mas por ter, assim como os humanos, faculdades cognitivas, emocionais e sensoriais às vezes até mais potentes que as dos homens. E talvez seja por isso que Rubião fique confuso diante de tais faculdades caninas, atribuindo-as ao fantasma do finado amigo.

Interessante observar que o olhar do cachorro exerce um papel medular nesse processo de confusão. Na maioria das cenas em que Rubião pressente a presença do espírito do filósofo no cão, é o olhar deste que provoca tal pressentimento. Emerge, nessas cenas, a intrigante dúvida advinda da ignorância humana diante do que se passa no interior de um bicho: o que esse cão sabe sobre mim?

Derrida detém-se precisamente nessa questão. Ao falar de sua experiência de ser observado por seu gato em um momento de nudez, admite: "ele tem seu ponto de vista sobre mim" (18). E pergunta-se, diante do animal que o olha: "Quem é este que eu sou?" (18).

O mal-estar que se instala em Derrida sob a força desse olhar que o perscruta deve-se, por um lado, ao fato de ele estar completamente nu e sentir vergonha de sua própria nudez. Isso, por causa do "olhar insistente do animal, um olhar benevolente ou impiedoso, surpreso ou que reconhece" (Derrida 16). Por outro lado, vê-se assaltado pela vergonha de sentir-se envergonhado de estar nu diante desse olhar. E é nesse duplo mal-estar que o filósofo reconhece o gato como um outro completamente outro e, portanto, dotado de um saber também outro em relação ao que os humanos têm do mundo e de si mesmos. Em outras palavras, aquele gato é um sujeito que tem um saber próprio sobre o que olha. Entretanto, não é possível, para nós humanos, sabermos exatamente o que ele sabe.

Em Quincas Borba, o desassossego que o olhar do cachorro causa em Rubião não deixa de ser da mesma ordem que a da cena derridiana, por advir do 
não saber do homem sobre o que o animal sabe. Numa das cenas, lê-se: "Olhou para o cão, enquanto esperava que lhe abrissem a porta. $O$ cão olhava para ele, de tal jeito que parecia estar ali dentro o próprio e defunto Quincas Borba; era o mesmo olhar meditativo do filósofo, quando examinava negócios humanos" (681). Graças aos engenhosos artifícios machadianos, Rubião, ao associar o cão ao filósofo, acaba por trazer à tona, involuntariamente, a imagem do cãofilósofo, própria do Cinismo. Entretanto, isso se dá de forma invertida, pois enquanto os filósofos cínicos adotavam o modo de ser do cão para justificarem os princípios filosóficos que sustentavam, aqui o cão é que assume, aos olhos de Rubião, o papel de filósofo. Como se vê nesta outra passagem: "mas então os olhos do cão, meio fechados de gosto, tinham um ar dos olhos do filósofo, na cama, contando-lhe coisas de que ele entendia pouco ou nada [...]. Rubião fechava os seus" (681). E ainda nesta, quando o personagem, depois de receber a visita do Major Siqueira e receber deste o conselho para se casar, ouve uma voz que lhe diz "por que não?": "Rubião, apavorado, olhou em volta de si; viu apenas o cachorro, parado, olhando para ele. Era tão absurdo crer que a pergunta viria do próprio Quincas Borba,- - ou antes do outro Quincas Borba, cujo espírito estivesse no corpo deste, que o nosso amigo sorriu com desdém" (711).

Se o olhar do cachorro de Rubião, como o do gato de Derrida, indica um ponto de vista animal, isso só corrobora a singularidade do que cada um desses outros vê, já que, como pontuou Eduardo Viveiros de Castro: "todo ser a que se atribui um ponto de vista será então sujeito; ou melhor, ali onde estiver o ponto de vista, também estará a posição do sujeito" (373). Trata-se, porém, de uma singularidade inapreensível pelo personagem, que o leva a interpretá-la como sendo a manifestação do filósofo morto e a projetar seus próprios desejos e apreensões no olhar de que é alvo. ${ }^{11}$ Algo que se afina com a seguinte afirmativa de Marjorie Garber: "the human fascination with withheld knowledge has often led to the depiction of the dog as philosopher" (109).

\footnotetext{
${ }^{11} \mathrm{O}$ olhar de Quincas Borba, o cão, também se cruza com o da personagem D. Fernanda, quase no final do romance, mas o que se estabelece é uma relação de cumplicidade entre os dois, e não de desconfiança de um em relação ao outro: "ele ficou a olhar para ela, e ela para ele, tão fixos e tão profundos, que pareciam penetrar no íntimo um do outro" (801).
} 
Ao conferir a um cachorro o estatuto de protagonista, ainda que mesclado ao ex-dono de mesmo nome, Machado de Assis não apenas rompe com a secular hierarquia das espécies e a dicotomia homem/animal, como também reconfigura o papel do animal na moderna literatura brasileira. Já não se trata de dar aos cães e outros animais o estatuto de meros coadjuvantes ou de símbolos de algo que os ultrapassa, mas de reconhecer neles as suas potencialidades enquanto viventes que compartilham conosco a experiência do mundo. Nesse sentido, mesmo ao antropomorfismo que perpassa a narrativa apresenta-se de forma intrincada (e matizada), uma vez que a animalidade do cão também impregna os personagens humanos, evidenciando um processo de

imprinting, de impregnação recíproca entre os seres postos em relação. À feição do que acontece também, como vimos, nos escritos de Lispector.

Assim, como "dog-writers," ambos os escritores não se furtam a sondar o que Garber chamou de "the once forbidden terrain of canine consciousness, with the objective of finding out not only whether dogs think, but what they think about us" (30). Dessa forma, eles ensinam aos seus leitores muito mais do que sabem, na condição de humanos, sobre as peculiaridades de algumas de nossas relações com outras espécies animais.

\section{Obras Citadas}

Agamben, Giorgio. Homo Sacer: O Poder Soberano e a Vida Nua, tradução de António Guerreiro, Presença, 1998.

—. "O fim do pensamento," tradução de Alberto Pucheu. Terceira Margem, vol. 9, no. 11, 2004, pp. 156- 59.

Amaral, Hélio Soares. Os Cães Filósofos: História da Filosofia de Resistência. Annablume, 2006.

Andrade, Carlos Drummond de. "Meu Companheiro." Contos de aprendiz, Companhia das Letras, 2012, pp. 55-60.

Azavedo, Artur. "Black." Os Melhores Contos de Artur Azevedo, seleção de Antonio Martins de Araújo, Global, 2001, pp. 138-40.

Azevedo, Carlos. Livro das Postagens. 7Letras, 2016.

Barthes, Roland. Como Viver Junto, tradução de Leyla Perrone-Moisés, Martins Fontes, 2003.

Bueno, Wilson. Cachorros do Céu. Planeta, 2005. 
Costa, Flávio Moreira. Os Melhores Contos de Cães \& Gatos. Ediouro, 2007.

Derrida, Jacques. O Animal que Logo Sou, tradução de Fábio Landa, U Estadual Paulista, 2002.

Dourado, Autran. Uma Vida em Segredo. Civilização Brasileira, 1964.

Galera, Daniel. Até o dia em que o cão morreu. Companhia das Letras, 2003.

Garber, Marjorie. Dog Love. Touchstone, 1997.

Guimarães Rosa, João. "Campo geral.” Corpo de baile, José Olympio, 1956, pp. 13-136.

Haraway, Donna. The Companion Species Manifesto: Dogs, People, and Significant Otherness. Prickly Paradigm, 2005.

-. When Species Meet. U of Minnesota P, 2008.

Hist, Hilda. Da Poesia. Companhia das Letras, 2017.

Lessa, Orígenes. Confissões de um Vira-Lata. Ediouro, 1972.

Lestel, Dominique. "The Question of the Animal Subject" Angelaki, vol. 19, no. 3,2014 , pp. 113-25.

Lispector, Clarice. "Bichos." A Descoberta do Mundo, Rocco, 2008, pp.221-25.

—. Quase de Verdade. Rocco, 1999.

—. Uma Aprendizagem ou O Livro dos Prazeres. Rocco, 1998.

—. Um Sopro de Vida. Rocco, 1999.

Machado de Assis, Joaquim Maria. "Memórias Póstumas de Brás Cubas." Obras Completas, vol.1, Nova Aguilar, 1985, pp.511-639..

—. "Miss Dollar." Contos Fluminenses, Garnier1989, pp.15-39..

—."Quincas Borba.” Obras Completas, vol. 1, Nova Aguilar, 1985, pp. 641806.

Maciel, Maria Esther. Literatura e Animalidade. Civilização Brasileira, 2016.

McHugh, Susan. Dog. Reaction, 2004.

Moser, Benjamin. Clarice, tradução de José Geraldo Couto, Cosacnaify, 2013.

Pina, Manuel António. Rui Lage. U de Coimbra, 2016.

Pompeia, Raul. "De madrugada." Contos, Civilização Brasileira, 1981, pp. 2123.

Queiroz, Rachel de. "Minha Amiga Flicka." A donzela e a moura torta, José Olympio, 1948, pp. 112-15.

Ramos, Graciliano. Vidas secas. Record, 1978.

Ramos, Nuno. Junco. Iluminuras, 2015.

-. Ó. Iluminuras, 2008. 
Ramos, Rogério, editor. Histórias Brasileiras de Cães. Positivo, 2014.

Reali, Giovanni, e Dario Antiseri. História da Filosofia, vol.1. Paulus, 1990.

Rio, João do. "Os cães." Au-Au: Três Contos de Cão, Dantes, 2004, pp. 77102.

Safina, Carl. Beyond Words: What Animals Think and Feel. Holt, 2015.

Telles, Lygia Fagundes. "Cachorro se Chama com Assobio." A disciplina do amor, Nova Fronteira, 1980, p. 74.

Viveiros de Castro, Eduardo. A Inconstância da Alma Selvagem. Cosacnaify, 2002. 